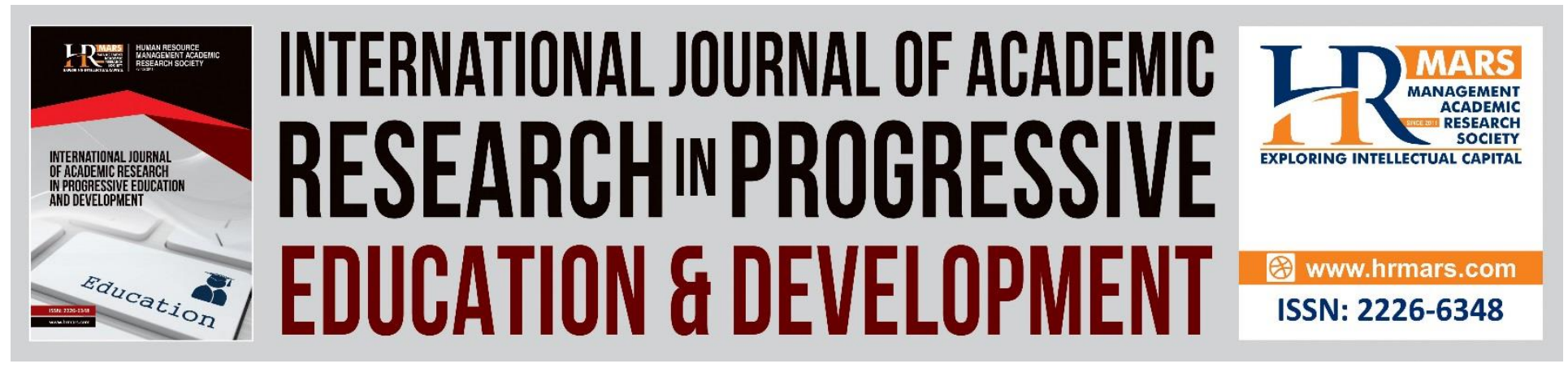

\title{
Teaching and Learning Calculus through Google Meet Platform During the Covid-19 Pandemic: Implementation and Evaluation
}

Mohd Syafiq Abdul Rahman, Mohamad Jumain Jalil, Mohammad Taufiq Abdul Ghani

To Link this Article: http://dx.doi.org/10.6007/IJARPED/v10-i2/10138

DOI:10.6007/IJARPED/v10-i2/10138

Received: 05 April 2021, Revised: 30 April 2021, Accepted: 20 May 2021

Published Online: 08 June 2021

In-Text Citation: (Rahman et al., 2021)

To Cite this Article: Rahman, M. S. A., Jalil, M. J., \& Ghani, M. T. A. (2021). Teaching and Learning Calculus through Google Meet Platform During the Covid-19 Pandemic: Implementation and Evaluation. International Journal of Academic Research in Progressive Education and Development, 10(2), 548-555.

Copyright: (c) 2021 The Author(s)

Published by Human Resource Management Academic Research Society (www.hrmars.com)

This article is published under the Creative Commons Attribution (CC BY 4.0) license. Anyone may reproduce, distribute, translate and create derivative works of this article (for both commercial and non-commercial purposes), subject to full attribution to the original publication and authors. The full terms of this license may be seen

at: http://creativecommons.org/licences/by/4.0/legalcode

Vol. 10(2) 2021, Pg. 548 - 555

http://hrmars.com/index.php/pages/detail/IJARPED

JOURNAL HOMEPAGE

Full Terms \& Conditions of access and use can be found at http://hrmars.com/index.php/pages/detail/publication-ethics 


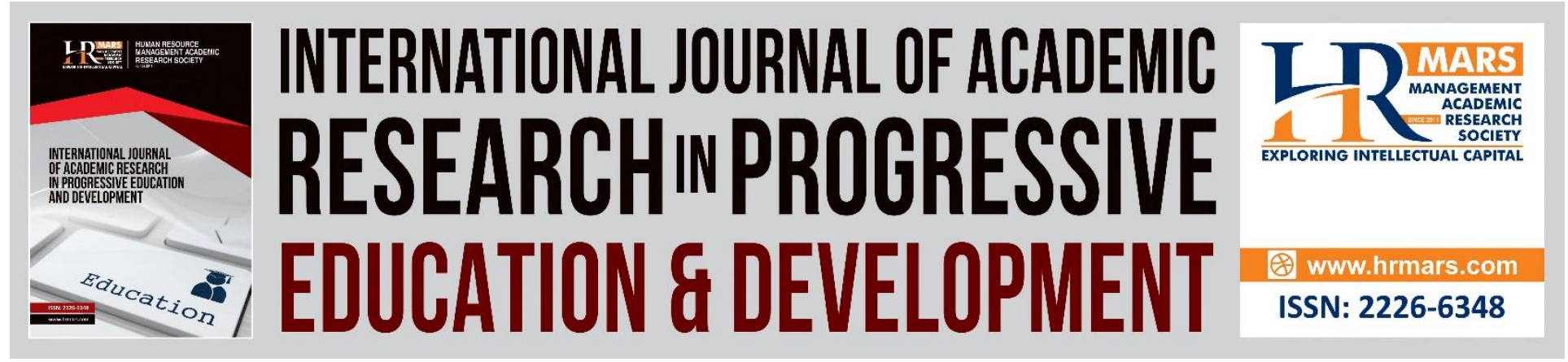

\title{
Teaching and Learning Calculus through Google Meet Platform During the Covid-19 Pandemic: Implementation and Evaluation
}

\author{
Mohd Syafiq Abdul Rahman ${ }^{1}$, Mohamad Jumain Jalil'², \\ Mohammad Taufiq Abdul Ghani ${ }^{3}$
}

${ }^{1}$ Department of Computer and Mathematical Sciences, Universiti Teknologi MARA, Cawangan Pulau Pinang, Permatang Pauh Campus, 13500 Permatang Pauh, Penang, Malaysia, ${ }^{2}$ Faculty of Chemical Engineering, Universiti Teknologi MARA, Cawangan Pulau Pinang, Permatang Pauh Campus, 13500 Permatang Pauh, Penang, Malaysia, ${ }^{3}$ Department of Modern Languages, Faculty of Languages and Communication, Universiti Pendidikan Sultan Idris, 35900, Tanjong Malim

Perak, Malaysia

\begin{abstract}
Millions of people are infected and hundred thousand are dead cause of the new coronavirus Covid-19. In order to break the chain of infection, government has instructed to Movement Control Order. Thus, all nonessential activities were put to a halt including higher education institutions. Ministry of Higher Education have suggested to move teaching and learning into online. Google Meet is a free video conference platform that can be used by Google account users. In the meantime, several devices such as iPad supported with Apple Pencil can also be used to teach during the lecture through Google Meet where live screen of iPad's note can be shared through Google Meet to transmit live video to remote students. Therefore, this paper is aims to present a method of remotely teaching calculus through video conference using Google Meet platform. The study also explored the preference and perceived ease of use of Google Meet through a set of questionnaire. This study found that high preference and positive acceptance from the students regarding remote teaching with Google Meet.

Keywords: Remote Teaching, Virtual Classroom, Video Conference, Tablet, Calculus.

Introduction

A new infectious virus Covid-19 was identified in Wuhan, China as the newest member of coronavirus family (Doug et al., 2020). The virus spread in over 200 countries around the world. At present, World Health Organization (WHO) reported more than 40 million confirmed cases and has reached one million deaths around the world (WHO, 2020). The virus spread rapidly from human to human transmission. Primarily, via oral and nasal droplet generated during sneezing,
\end{abstract}


coughing and talk. Physical contact with the patients and lack of proper ventilation is a closed area are also the risks to get infected (Al-Rohaimi \& Al Otaibi, 2020). What makes this virus has developed into a pandemic is because no vaccine yet to be found (Anderson et al., 2020). However, researchers worldwide are racing to develop the vaccine, and some are already under clinical trials (Al-Rohaimi \& Al Otaibi, 2020). Most governments have taken strict action to resist the virus of spreading in their countries. Malaysia is not excepted. Ministry of Health (MoH) started with enforcement of health screening at all borders and entry points to prevent the disease transmission from spreading in the country. To enhance the enforcement, the government implemented Movement Control Order (MCO) countrywide (Shah et al., 2020). Most nonessential activities are affected such as business, religious activities, sports and also learning as they are put to halt. Thus, educational institutions are suggested by Ministry of Higher Education (MoHE) to move their teaching and learning into online (Malaysian Ministry of Higher Education, 2020).

Universiti Teknologi MARA (UiTM), the largest educational institution in Malaysia, developed online portal called i-Learn which is now known as UFuture as a platform for lecturers to flip the classroom to online classroom (Chung et al.,2020). This initiative taken since 15 years ago has indirectly prepared the readiness of lecturers and students for online learning. During the pandemic Covid-19, all universities has immediately moved all classes to open and distance learning (ODL) as instructed by the government. Since the outbreak, the use of online platform has becoming a new norm for teachers and students (Lee \& Yeong, 2020). There are many options available for teachers to flip their class either by using online learning management systems (Edmodo, ClassDojo and Google Classroom), Massive Open Online Course (MOOC) platforms (Coursera, Udemy and Open Learning) and also online video conference platforms (Zoom, Skype and Google Meet). Google Classroom is one of the best platforms for teaching and learning around the world as it is very effective and flexible that can be accessed from laptops, PCs and mobiles easily by anyone who has Google account (Albashtawi and Al Bataineh, 2020). However, in order to optimize the ODL, strong internet connection should be provided (Ana et al., 2020).

Calculus is a fundamental course for science, technology, engineering, and mathematics (STEM) students before they go to advanced classes (Smolinsky et al.,2018). In calculus, the topics covered are function and graphs, limits and continuity, and techniques of differentiation and integration and its applications. Calculus is important especially in the fields of engineering and medical. In engineering there are many applications of calculus, for example, optimization problems, finding area and volume and also calculating fluid pressure (Anton,2009). In medical, modelling population growth and the spread of disease are examples of application of calculus in real life. At present, many researchers have developed mathematical model for the spread of the Covid-19 (Ivorra et al., 2020; Aviv-Sharon and Aharoni, 2020; Roosa et al., 2020; Ngonghala, 2020). This shows that mathematics is also plays important role during this pandemic time to estimate the number of cases for the good of economic and social.

During this pandemic, education has moved to online. Calculus course can be taught online because it does not involve hands-on activities. The problem that faced in the calculus course is that it is a symbolic scientific language. The mathematical formulas are easier to be hand-drawn rather than typing on a keyboard (Fan et al., 2021). Furthermore, interactive learning is needed in online teaching to achieve knowledge transfer. To replace blackboard, extra devices 
are needed in teaching mathematics such as stylus or pen tablet. This paper presents a method of remotely teaching calculus using Google Meet among engineering and pharmacy students. The study explores how the students experienced studying calculus remotely.

\section{Materials and Procedures}

UiTM has subscribed G Suite that comes in bundle including all the Google applications. As a subscriber, all UiTM staffs are privileged to use Google Meet with up to 250 number of participants and can held more than 1-hour meeting. As a gesture of goodwill, Google allows all users to use Google Meet for up to 24 hours of maximum meeting length during the pandemic. This paper will discuss on teaching calculus remotely with the use of Google Meet and iPad.

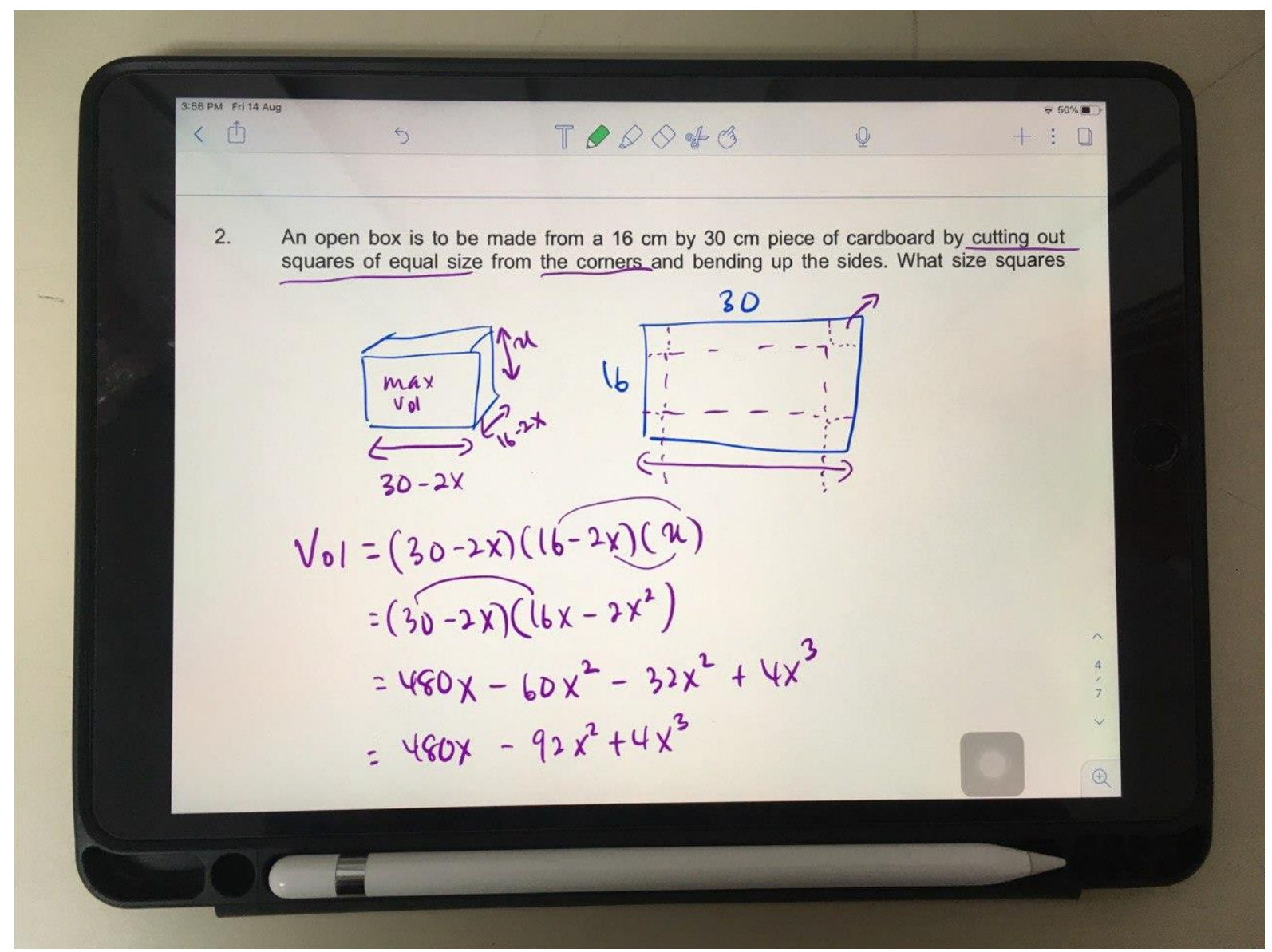

Figure 1. Apple Pencil used to write on iPad during lecture session on Google Meet. (Rahman, 2020)

\section{Lectures}

Students were well aware of using online video conference applications such as Google Meet, Zoom, Skype and Microsoft Teams. Devices that were used by students are laptops and mobile phones. Before the lectures started, lecturers explained basic rules during lecture sessions such as the microphones must always on mute unless necessary, attendance form will be given at the end of lectures and lectures will be recorded for future reference. Students were prepared with 
lecture notes that they have bought from the early semester before the pandemic started. However, some of them left the notes at their hostels. Therefore, PDF files were shared with them through Telegram group and Padlet. The lectures were conducted based on the notes.

\section{The Setup}

Since 2015, Apple has introduced Apple Pencil to be used with iPad. Various models of iPads can support the Pencil, starting with the cheapest iPad 2019 until the high-end model iPad Pro 2020. In this paper, mid-range iPad was used which is the iPad Air 3 supported with Apple Pencil $1^{\text {st }}$ Generation. The simple setup is shown as in Figure 1 (Rahman, 2020). Live screen of iPad is shared (presented) in Google Meet. The concept is similar to teaching in physical classroom with blackboard. According to Fan et al (2021), teaching mathematics is easier to be hand drawn rather than typing on a keyboard because it involves symbolic scientific language especially when writing the formulas. So, this kind of setup is the best solution to imitate the writing on a blackboard in a physical classroom. A Google Meet lecture session was conducted every week. A total of students participated in the sessions were 84 students. Every session was recorded. The recorded videos were posted to the Padlet for them to rewatch in case they missed some points during the sessions. From Google Meet, the recorded session is stored in cloud Google Drive. The drawback of Google Meet is if the students' internet connection is bad, they might be having lag and delays during the live stream. Therefore, uploading the recorded session in Padlet or share the video link is very important to make sure the students are not left behind in their study.

\section{Assessments}

Three assessments were given to the students to measure their understanding. Assessment was given every end of the chapter to test their knowledge on the particular chapter. Students were given 4 hours to finish their assessments. Preparation to scan and upload were included in the 4. Their answer scripts were scanned and submitted as PDF files through Google Form link that was provided in the Padlet. Google Form was chosen as a platform for the students to upload their answer because to avoid the other students to see their friends answer who submitted earlier. Only the lecturer can access the responded forms.

All answer scripts were graded by lecturers and returned them to the students within a week. The answer scripts were graded manually from the iPad. The lecturers can freely mark the scripts on the PDF files.

\section{Attendance and Survey}

At the end of each lecture, attendance forms were given in the Google Meet chat section. Basic personal details such as name, matric number and class group. In the form also, comment section was available for to the students to leave comments and feedbacks based on the particular lecture that they have attended.

\section{Methodology}

The descriptive study method was employed to measure the overall feedback and explore student's experience based on remote teaching of calculus through Google Meet platform. A set of questionnaires consisted of two main construct which are the preference of Google Meet and 
the perceived ease of use of Google Meet, was administered among 84 students from Faculty of Pharmacy and Faculty of Electrical Engineering at Universiti Teknologi MARA, Penang Campus. The students were chosen through purposive random sampling technique to participate in this study. A descriptive quantitative analysis was used to analyse the data obtained by using IBM SPSS 27 statistical software. The results are presented in the next chapter.

\section{Results and Discussion}

Student from Faculty of Pharmacy and Faculty of Electrical Engineering were involved in this survey. 8 series of lectures were delivered during the pandemic until the end of the semester were conducted entirely through Google Meet. A total of 56 participants completed the survey. Of them, 29 participants (52\%) were from Faculty of Pharmacy and the remaining are from Faculty of Electrical Engineering. All of them were in second semester.

Participants were asked how strongly they agreed that they enjoyed calculus lectures on Google Meet where 14 participants (25\%) strongly agreed, 28 participants (50\%) agreed and 14 participants (25\%) neither agreed nor disagreed. Majority of the students enjoyed learning calculus through Google Meet platform. The use of technology influences all aspects of digital natives who are born in technological era. The rapid growth of technology affects the preference of young generation in communication, socialise including teaching and learning. According to Prensky (2001), the digital natives preferred to received information in real time and able to multi-task more efficiently. Hence, this result proves that the students have high perceived of enjoy in learning calculus through online platform especially during Covid-19 pandemic.

The survey also asked about the speed of their internet access where 4 participants (7\%) very agreed, 39 participants (70\%) agreed, 10 participants (18\%) neither agreed nor disagreed and 3 participants (5\%) disagreed. Majority of them have stable and high-speed internet connectivity. The reasonable price of internet data in marketplace gives them opportunities to subscribe bigger internet data quota for learning purpose. Besides, many providers also offer unlimited internet data with reasonable and affordable price among student. However, there are $5 \%$ of students do not have high speed of internet connection. This might be the location does not support the internet connectivity. Hence, this will affect their preference in learning through Google Meet. Therefore, the educators should consider for some students who have low internet bandwidth or slow internet connectivity by providing asynchronous online lecture.

Participants were asked how strongly they prefer Google Meet rather than other video conference platforms such as Zoom and Microsoft Teams where 32 participants (57\%) strongly agreed, 18 participants (32\%) agreed and 3 participants (11\%) neither agreed nor disagreed. This also can be reflected on the next questions where they were asked how easy Google Meet was to be used where 34 participants (61\%) strongly agreed and 22 participants (39\%) agreed. Google Meet is a straightforward platform where all users can join the meeting by simply clicking the invitation link. In addition, the interface is user friendly and not complicated. Furthermore, Google is one of the largest internet services. Over one billion active monthly users visited Google.com. On top of that, Google Gmail's which is the email platform has 1.5 billion active users. It is unsurprisingly that almost every student has Google account. So, they can sign in the Google Meet with their Google account easily especially with the single sign-on system that allows users to sign-in multiple platforms without having to remember many username and 
Vol. 10, No. 2, 2021, E-ISSN: $2226-6348$ @ 2021 HRMARS

passwords (Bauer et al., 2013). To sign-in Google Meet, students just have to click the invitation link and the platform will appear in the browser without have to install additional application on their PCs or laptops.

\section{Conclusions}

An effective teaching and learning platform must be well structured and relevant to the current situation's need. In this regard, this study presented a method of remotely teaching calculus through Google Meet among students during Covid-19 pandemic. During the pandemic, remote teaching is the only option available in order to break the chain of the Covid-19. To make sure that no students are left behind, using a simple application like Google Meet where everyone can access for free is the best option. Majority of the students prefer to use Google Meet platform due to its valuable features which other tools do not offer.

\section{Acknowledgement}

This work was supported by Universiti Teknologi MARA Cawangan Pulau Pinang, Malaysia.

\section{Corresponding Author}

Mohd Syafiq Abdul Rahman

Department of Computer and Mathematical Sciences, Universiti Teknologi MARA, Cawangan Pulau Pinang, Permatang Pauh Campus, 13500 Permatang Pauh, Penang, Malaysia

Email: mohdsyafiq5400@uitm.edu.my

\section{References}

Al-Rohaimi, A. H., \& Al Otaibi, F. (2020). Novel SARS-CoV-2 outbreak and COVID19 disease; a systemic review on the global pandemic. Genes \& Diseases.

Albashtawi, A. H., \& Al Bataineh, K. B. (2020). The effectiveness of google classroom among EFL students in Jordan: An innovative teaching and learning online platform. International Journal of Emerging Technologies in Learning, 15(11), 78 - 88.

Ana, A., Minghat, A. D., Purnawarman, P., Saripudin, S., Muktiarni, M., Dwiyanti, V., \& Mustakim, S. S. (2020). Students' Perceptions of the Twists and Turns of E-learning in the Midst of the Covid 19 Outbreak. Romanian Journal for Multidimensional Education/Revista Romaneasca pentru Educatie Multidimensionala, 12.

Anderson, R. M., Heesterbeek, H., Klinkenberg, D., \& Hollingsworth, T.D. (2020). How will country-based mitigation measures influence the course of the COVID-19 epidemic? Lancet, 395, 931-934.

Anton, H., Bivens, I., \& Davis, S. (2009). Calculus. 8Th Ed. John Wiley.

Aviv-Sharon, E., \& Aharoni, A. (2020). Generalized logistic growth modeling of the COVID-19 pandemic in Asia. Infectious Disease Modelling, 5, 502-509.

Bauer, L., Bravo-Lillo, C., Fragkaki, E., \& Melicher, W. (2013). A comparison of users' perceptions of and willingness to use Google, Facebook, and Google+ single-sign-on functionality. In Proceedings of the 2013 ACM workshop on Digital identity management, 25-36.

Chung, E., Subramaniam, G., \& Dass, L. C. (2020). Online Learning Readiness Among University Students in Malaysia Amidst Covid-19. Asian Journal of University Education, 16(2), 45-58. 
INTERNATIONAL JOURNAL OF ACADEMIC RESEARCH IN PROGRESSIVE EDUCATION AND

DEVELOPMENT

Vol. 10, No. 2, 2021, E-ISSN: 2226-6348 @ 2021 HRMARS

Doug, K., Couldwell, W. T., \& Rutka, J. T. (2020). Introduction. On pandemics: The impact of COVID-19 on the practice of neurosurgery. J Neurosurg, 1-2.

Fan, X., Li, W., Wang, Z., Sun Y., \& Su, L. (2021) The Analysis of Higher Mathematics Teaching Strategy Based on the Innovative Teaching Mode. Advances in Intelligent Systems and Computing, 1195.

Ivorra, B., Ferrández, M. R., Vela-Pérez, M., \& Ramos, A. M. (2020). Mathematical modeling of the spread of the coronavirus disease 2019 (COVID-19) taking into account the undetected infections. The case of China. Communications in nonlinear science \& numerical simulation, 88, 105303.

Lee, Z., \& Yeong, F. M. (2020). Online conferencing platform provides opportunity for reciprocal teaching. Biochemistry and Molecular Biology Education.

Ministry of Higher Education. (2020). Pengendalian program akademik di Universiti Awam (UA) dan Institusi Pendidikan Tinggi Swasta (IPTS). Retrieved from http://www.mohe.gov.my/en/media-mohe/press-statement/1031-pengendalianprogram-akademik-di-universiti-awam-ua-dan-institusi-pendidikan-tinggi-swasta-ipts

Ngonghala, C. N., Iboi, E., Eikenberry, S., Scotch, M., Maclntyre, C. R., Bonds, M. H., \& Gumel, A. B. (2020). Mathematical assessment of the impact of non-pharmaceutical interventions on curtailing the 2019 novel Coronavirus. Mathematical biosciences, 325, 108364.

Prensky, M. (2001). Digital Natives, Digital Immigrants Part 2: Do They Really Think Differently? On the Horizon, 9(6), 1-6.

Rahman, M. S. A. (2020). Teaching and learning calculus through video conference during the Covid-19 pandemic: Google Meet. Creative and Innovative Teaching Practices During COVID-19 Movement Control Order (MCO), 1, 88-95.

Roosa, K., Lee, Y., Luo, R., Kirpich, A., Rothenberg, R., Hyman, J. M., Yan, P., \& Chowell, G. (2020). Short-term Forecasts of the COVID-19 Epidemic in Guangdong and Zhejiang, China: February 13-23, 2020. Journal of clinical medicine, 9(2), 596.

Shah, A. U. M., Safri, S. N. A., Thevadas, R., Noordin, N. K., Rahman, A. A., Sekawi, Z., Sultan, M. T. H. (2020). COVID-19 Outbreak in Malaysia: Actions Taken by the Malaysian Government. International Journal of Infectious Diseases.

Smolinsky, L., Olafsson, G., Marx, B. D., \& Wang, G. (2018). Online and Handwritten Homework in Calculus for STEM Majors. Journal of Educational Computing Research, 073563311880080.

World Health Organization. (2020). WHO Coronavirus Disease (COVID-19) dashboard. Retrieved from https://covid19.who.int/ 